\title{
Stereotactic guide for posterior approach to lateral ventricle
}

\author{
Aatman Chand ${ }^{1}$, Ashis K. Chand ${ }^{1}$, Arun Angelo Pati ${ }^{2^{*}}$ (D) and Manmeet Singh Chhabra ${ }^{1}$
}

\begin{abstract}
Background: Free-hand tapping of the lateral ventricle through the posterior approach is a standard procedure. There are occasions, however, when more than one pass is needed. One way to make it easy and safe is to use a neuro-navigation approach. This requires extra setup. Therefore, the authors in this paper describe the use of a simple device to accurately place the catheter tip in the frontal horn.

Main body: The device is rectangular with two open arms with co-linear free ends. Based on axial CT or MR images, a trajectory that travels within the ventricle from the posterior to the anterior horn is chosen. The anterior and posterior points of the trajectory are marked on the scalp. A burr hole is placed at the posterior point. The anterior free end is then attached to the anterior trajectory point on the scalp using an EKG pad and to the posterior to a plug placed in the burr hole. The ventricle is tapped through a central hole in the burr hole plug. All 12 patients had accurate catheter placement at the first attempt using this system.
\end{abstract}

Short conclusion: This is a simple device that used CT or MR images and surface markings to accurately tap the ventricle.

Keywords: Posterior approach, Ventricular guide, Catheter placement

\section{Background}

Though it is relatively easy to tap the lateral ventricle from the posterior approach using the free-hand technique, there are occasions when surgeons can have difficulty with this procedure due to the small size of the ventricle or the presence of a clot in the ventricle. Furthermore, tapping the lateral ventricle from the posterior approach can be a little more challenging than the anterior approach, especially if the desired tip-point is the frontal horn, because of the length of the passage to the frontal horn from the posterior approach $[1,2]$. Therefore, surgeons often have use navigation or guidance systems, ultrasound imaging, and ventricular guiding devices to tap the ventricles with a great degree of success [3-13]. In this paper, the authors present a simple

\footnotetext{
* Correspondence: aapatil@cox.net

2Department of Surgery, Creighton University School of Medicine, 7710

Mercy Road, Suite 501, Omaha, NE 68124, USA

Full list of author information is available at the end of the article
}

device to tap the ventricle from the posterior approach using preoperative CT or MR images.

\section{Main text}

The device is made of aluminum

It is rectangular (Fig. 1) with two open arms (anterior and posterior) and a connecting arm. The free end of the anterior arm has a small groove in it, and the free end of the posterior arm has a hole in it. These two openings are co-linear. The device has burr hole plugs. The outer end of the plugs is rounded up to a diameter which will accommodate the hole in the posterior arm of the device and a standard bur hole. There is a central hole through the burr hole plug.

\section{Method}

\section{Steps of the operation}

(1) CT or MR axial images are reviewed (Fig. 2a). The image that shows the frontal and occipital horn in continuity (trajectory image) is used for targeting. The

Springer Open

(c) The Author(s). 2021 Open Access This article is licensed under a Creative Commons Attribution 4.0 International License, which permits use, sharing, adaptation, distribution and reproduction in any medium or format, as long as you give appropriate credit to the original author(s) and the source, provide a link to the Creative Commons licence, and indicate if changes were made. The images or other third party material in this article are included in the article's Creative Commons licence, unless indicated otherwise in a credit line to the material. If material is not included in the article's Creative Commons licence and your intended use is not permitted by statutory regulation or exceeds the permitted use, you will need to obtain permission directly from the copyright holder. To view a copy of this licence, visit http://creativecommons.org/licenses/by/4.0/. 


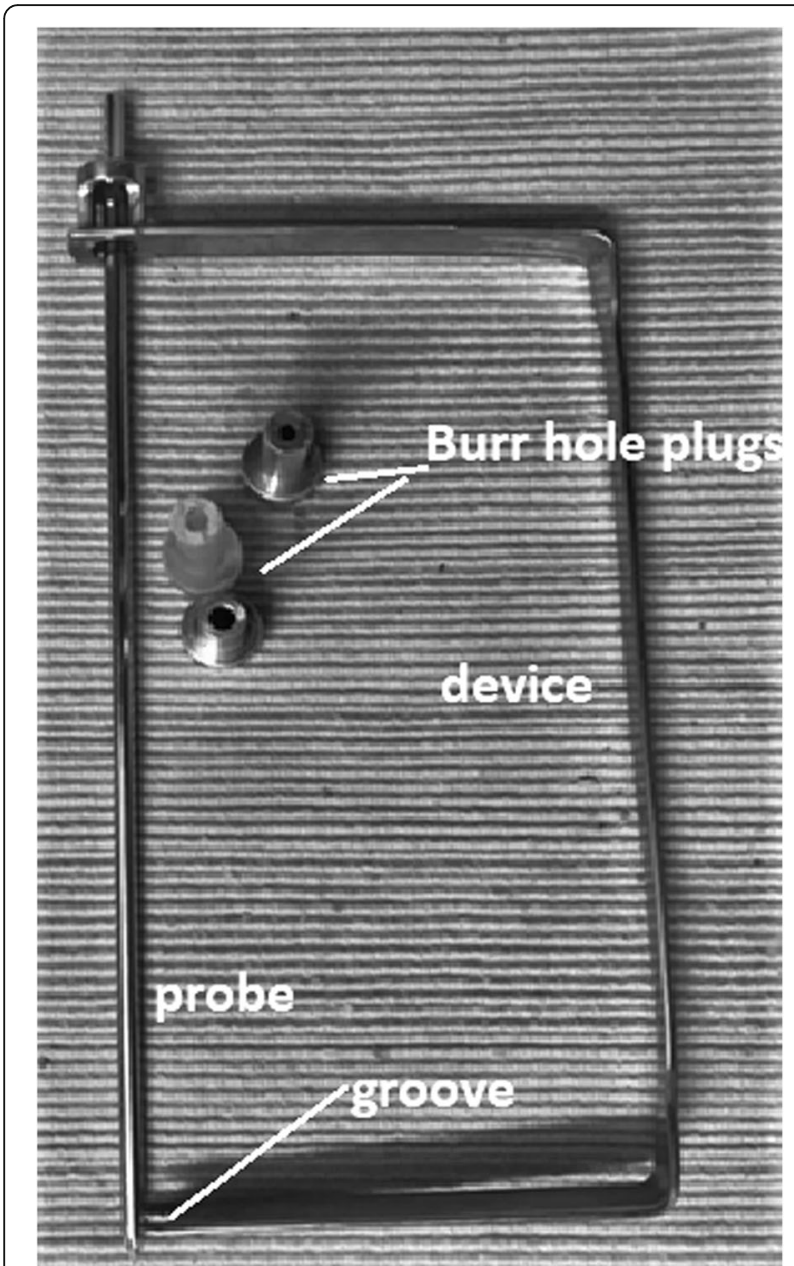

Fig. 1 Ventricular guiding system

trajectory to the frontal horn is chosen to minimize the travel distance of the catheter through brain tissue and have a continuous passage within the intraventricular space. (2) The trajectory $\mathrm{XY}$ is marked on the image. The midline $(\mathrm{AB})$ is marked. (3) Distances AX and BY are measured. The length from point $B$ to the frontal horn is measured. This is used as the length of the ventricular catheter. (4) Then, the distance between the glabella to point $\mathrm{A}$ is calculated by multiplying the number of scans between them by the scan thickness. Similarly, the distance between the inion to point $B$ is calculated by multiplying the number of scans between the inion and point $B$ by the scan thickness. (5) Points A and B are marked on the patient's head. (6) Then, using XY and BY, distances $\mathrm{X}$ and $\mathrm{Y}$ points are marked on the patient's head. (7) An EKG pad is stuck on the forehead with its center on point A. (8) A burr hole is placed at point B. A burr hole plug is plugged into the burr hole (Fig. 2b). Then groove at the end anterior arm is placed in the lead attachment of the EKG pad, and the posterior arm is attached to the burr hole plug. The ventricle is then tapped through an appropriate size hole in the center of the burr hole plug.

\section{Clinical data}

Twelve patients with hydrocephalus had ventricular catheters placed using this device via the posterior approach. Postoperative scans (Fig. 3a, b) show satisfactory catheter placements. Two patients had posterior fossa tumors, 3 had thalamic tumors, and 7 had meningitis. There was no complication from the procedures.

\section{Discussion}

This is a simple device in which the axis of the device is co-linear with the probe trajectory. The target can therefore be reached by aligning the axis of the device with the trajectory. The trajectory is chosen to minimize the travel distance of the catheter through brain tissue and have a continuous passage within the intraventricular space. This reduces the risk of neurological complications. The anterior and posterior ends of the trajectory can be obtained directly from the scans. Marking of the anterior axis point is fairly accurate because the forehead is relatively flat. Marking of the posterior axis point can encounter errors because the posterior surface can have varying degrees of curves. However, if the anterior trajectory point is accurate, the probability to hit the target is high.

The markings for the entry and anterior trajectory point on the scalp, the determination of catheter length, and the trajectory are based on individual ventricular anatomy using existing imaging studies. This also allows the surgeon to customize the approach for each patient. Posteriorly, the burr hole plug which serves as the probe holder also gives stability to the posterior arm. Anteriorly, the groove in the free end of the anterior arm is stabilized by the EKG pad. Furthermore, the system is extremely light. This prevents it from sagging. The stability can be further improved by replacing the EKG pad with a small screw inserted into the skull.

There are other methods to tap the ventricle in difficult situations [3-11]. They include the neuronavigation systems and catheter placement using ultrasound guidance. They too are fairly accurate but need extra equipment in the operating room and need a little longer time to perform. There is another guidance system in existence which is based on the assumption that catheter trajectory perpendicular to the skull surface will put it into the ventricle [12]. This system has a tripod with the probe holder in the middle of it. The tripod keeps the probe holder perpendicular to the skull. Though this is true in a large percentage of patients, in a patient with an unusual slope to the cranial surface, the trajectory may not drop into the ventricle [13]. Furthermore, for the posterior approach, when the aim is to get 



Fig. 2 a Trajectory XY. b Application of the system
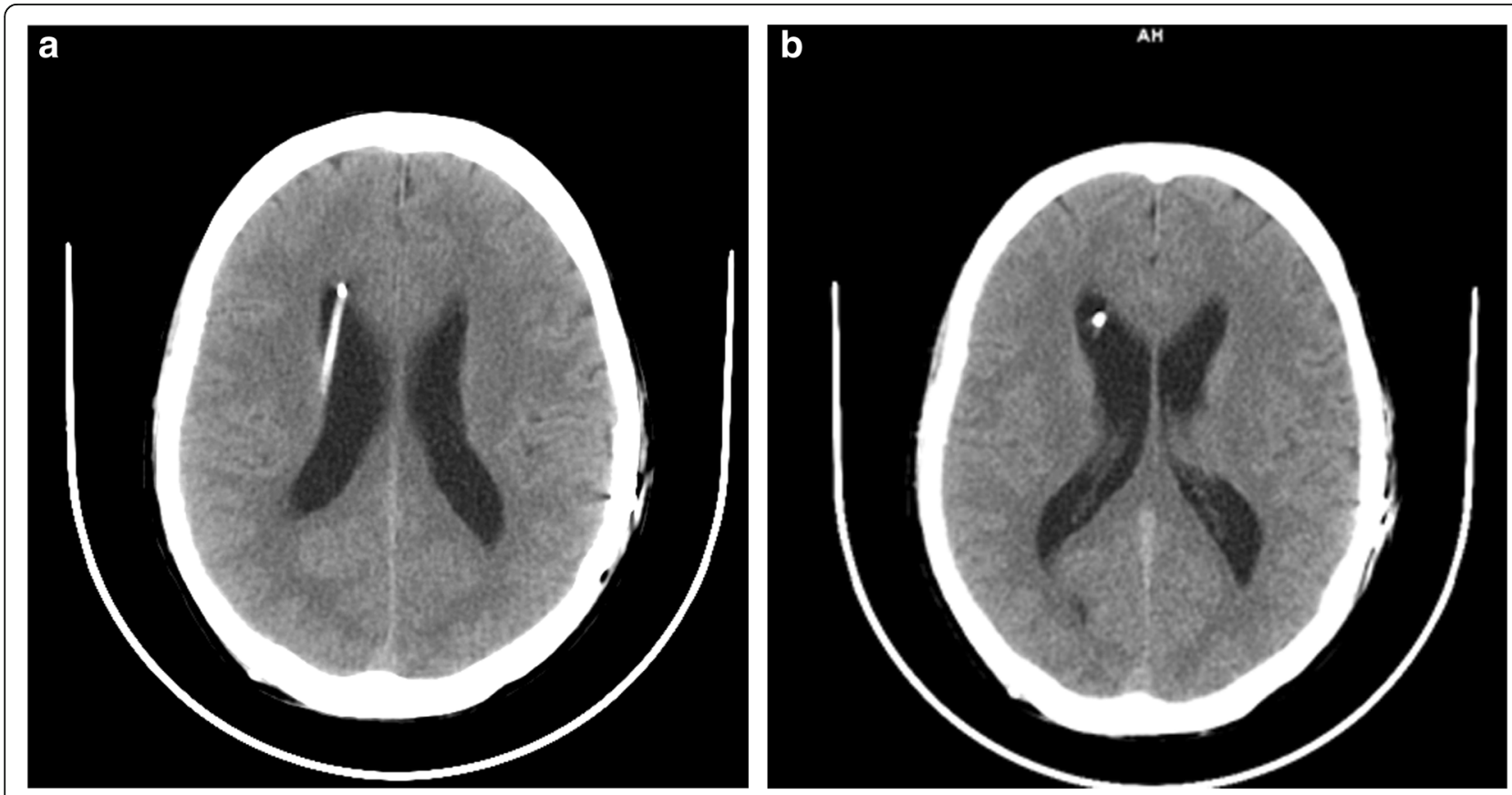

Fig. 3 a CT image showing the catheter tip traversing towards the tip of the frontal horn. $\mathbf{b}$ A more caudal image showing the tip of the catheter in the anterior part of the frontal horn 
the catheter tip into the frontal horn with minimal travel through the brain substance, this system will not provide optimal trajectory. The new system described in this paper overcomes these problems because it is imagebased; the surgeon can plan optimal trajectory based on the patient's CT images. The authors hope to get other centers to try this system and get their input. Though the present experience is with large ventricles, it is hoped that with increased use of it, its utility with smaller ventricles will become evident.

\section{Conclusion}

This a simple and accurate system to tap the lateral ventricle from the posterior approach. It uses pre-existing images to obtain measurements and plan the approach. This makes the procedure accurate, patient-specific, and safe.

\section{Abbreviations}

$\mathrm{CT}$ : Computed tomography; MR: Magnetic resonance; EKG: Electrocardiogram

\section{Acknowledgements}

None

\section{Authors' contributions}

AC collected the data. AKC invented the device, used the system, and provided feedback. AAP invented the device and wrote the paper. MSC used the system and provided feedback. The authors have read and approved this paper.

\section{Funding}

There was no funding for this paper.

\section{Availability of data and materials}

This is only a technical note. Images available to the author are in the paper.

\section{Declarations}

\section{Ethics approval and consent to participate}

This is a technical note paper with a retrospective look at the results. There is no case history on any of the patients. "For this type of study, formal consent is not required."

There is no identifying information about the patients in the paper.

\section{Consent for publication}

Not applicable

\section{Competing interests}

The authors declare that they have no competing interests.

\section{Author details}

'Department of Neurosurgery, St. John's Medical Academy, Bangalore, India. ${ }^{2}$ Department of Surgery, Creighton University School of Medicine, 7710 Mercy Road, Suite 501, Omaha, NE 68124, USA.

Received: 27 November 2020 Accepted: 15 April 2021

Published online: 07 June 2021

\section{References}

1. Lind C, Tsai A, Law A, Lau H, Muthiak K. Ventricular catheter trajectories from traditional shunt approaches: a morphometric study in adults with hydrocephalus. J J Neurosurg. 2008;108(5):930-3. https://doi.org/10.3171/ JNS/2008/108/5/0930.

2. Tayebi Meybodi K, Hoseinzadeh E, Ahmadi M, Taghvaei M, Saberi H. Reevaluation of classic posterior ventricular puncture sites using a 3- dimensional brain simulation model. World Neurosurg. 2017 Nov;107:22-7. https://doi.org/10.1016/j.wneu.2017.07.134.

3. Sarkar H, Thakar S, Kumar S, Moorthy R, Rajshekhar V. A computed tomography-based localizer to determine the entry site of the ventricular end of a parietal ventriculoperitoneal shunt. Neurosurgery. 2011;68(1 Suppl Operative):162-7.

4. Sarrafzadeh A, Smoll N, Schaller K. Adjustable guiding device and DICOM (Digital Imaging and Communications in Medicine) image-reading software assistance (for example, using a mini-tablet) based on preoperative CT imaging. Trials. 2014;15:478.

5. Wilson TJ, Stetler WR Jr, Al-Holou WN, Sullivan SE. Comparison of the accuracy of ventricular catheter placement using freehand placement, ultrasonic guidance, and stereotactic neuronavigation. J Neurosurg. 2013; 119(1):66-70. https://doi.org/10.3171/2012.11.JNS111384.

6. Xu LW, Sussman ES. Li G Frameless, electromagnetic image-guided ventriculostomy for ventriculoperitoneal shunt and Ommaya reservoir placement. Clin Neurol Neurosurg. 2016;147:46-52. https://doi.org/10.1016/j. clineuro.2016.05.024

7. Eisenring CV, Burn F, Baumann M, Stieglitz LH, Kockro RA, Beck J, et al. sEVD-smartphone-navigated placement of external ventricular drains. Acta Neurochir (Wien). 2020;162(3):513-21 Journal of neurosurgery 2008, 108(5) 930-3.

8. Thomale UW, Knitter T, Schaumann A, Ahmadi SA, Ziegler P, Schulz M, et al. Smartphone-assisted guide for the placement of ventricular catheters. Childs Nerv Syst. 2013;29(1):131-9. https://doi.org/10.1007/s003 81-012-1943-1.

9. Gil Z, Siomin V, Beni-Adani L, Sira B, Constantini S. Ventricular catheter placement in children with hydrocephalus and small ventricles: the use of a frameless neuronavigation system. Childs Nerv Syst. 2002;18(1-2):26-9. https://doi.org/10.1007/s00381-001-0550-3.

10. Azeem SS, Origitano TC. Ventricular catheter placement with a frameless neuronavigational system: a 1-year experience. Neurosurgery. 2007;60:243-7.

11. Gautschi OP, Smoll NR, Kotowski M, Schatlo B, Tosic M, Stimec B, et al. Nonassisted versus neuro-navigated and XperCT-guided external ventricular catheter placement: a comparative cadaver study. Acta Neurochir (Wien). 2014;156(4):777-85. https://doi.org/10.1007/s00701-014-2026-8.

12. Ghajar JB. A guide for ventricular catheter placement. Technical note. J Neurosurg. 1985;63(6):985-6. https://doi.org/10.3171/jns.1985.63.6.0985.

13. Park J, Son W, Park KS, Kim MY, Lee J. Calvarial slope affecting accuracy of Ghajar Guide technique for ventricular catheter placement. J Neurosurg. 2016 May;124(5):1429-33. https://doi.org/10.3171/2015.5.JNS15226.

\section{Publisher's Note}

Springer Nature remains neutral with regard to jurisdictional claims in published maps and institutional affiliations.

\section{Submit your manuscript to a SpringerOpen ${ }^{\odot}$ journal and benefit from:}

- Convenient online submission

- Rigorous peer review

- Open access: articles freely available online

- High visibility within the field

- Retaining the copyright to your article

Submit your next manuscript at $\boldsymbol{\nabla}$ springeropen.com 